\title{
"This is a Controlled Invasion": The Czech President Miloš Zeman's Populist Perception of Islam and Immigration as Security Threats
}

\author{
Vladimír Naxera and Petr Krčál \\ University of West Bohemia in Pilsen
}

\begin{abstract}
This paper is a contribution to the academic debate on populism and Islamophobia in contemporary Europe. Its goal is to analyze Czech President Miloš Zeman's strategy in using the term "security" in his first term of office. Methodologically speaking, the text is established as a computer-assisted qualitative data analysis (CAQDAS) of a data set created from all of Zeman's speeches, interviews, statements, and so on, which were processed using MAXQDA11+. This paper shows that the dominant treatment of the phenomenon of security expressed by the President is primarily linked to the creation of the vision of Islam and immigration as the absolute largest threat to contemporary Europe. Another important finding lies in the fact that Zeman instrumentally utilizes rhetoric such as "not Russia, but Islam", which stems from Zeman's relationship to Putin's authoritarian regime. Zeman's conceptualization of Islam and migration follows the typical principles of contemporary right-wing populism in Europe.
\end{abstract}

\section{Keywords}

populism; Miloš Zeman; security; Islam; Islamophobia; immigration; threat

"It is said that several million people are prepared to migrate to Europe. Because they are primarily Muslims, whose culture is incompatible with European culture, I do not believe in their ability to assimilate" (Miloš Zeman). ${ }^{1}$

\section{Introduction}

The issue of populism is presently one of the crucial political science topics on the levels of both political theory and empirical research. Research has dealt

\footnotetext{
* Vladimír Naxera (corresponding author), Department of Politics and International Relations, University of West Bohemia, Pilsen, Univerzitní 8, 30614 Pilsen, Czech Republic; vnaxera@kap.zcu.cz; Petr Krčál, Department of Politics and International Relations, University of West Bohemia, Pilsen, Univerzitní 8, 30614 Pilsen, Czech Republic; petrkrcal@gmail.com.

1 All verbatim quotations listed in the text come from the data corpus that we created and processed. Therefore, we do not consider it purposeful to provide specific links that would otherwise disturb the flow of the text. This is generally a standard method in the whole-corpus approach in data analysis. In this case, links would not only be disruptive, but wholly useless, as the whole-corpus approach analyzes the actor as such - thus, for instance, the specific interview/speech/text in which the actor uttered the information is not relevant.
}

192

(c) BY-NC-ND (C) 2018 Vladimír Naxera and Petr Krčál, published by Sciendo.

This work is licensed under the Creative Commons Attribution-NonCommercial-NoDerivs 4.0 License. 
with a wide spectrum of political actors - the populist behavior of regimes as wholes (e.g., Antal 2017); political parties, movements, and associations (e.g., Mudde 2007; Novotný 2017; Stulík 2016); and the level of individuals (e.g., Hawkins 2009). In all these forms of populism, a concept that is markedly dealt with is that of the endangerment of "pure people" by variously defined enemies, who can be corrupt elites (Wolkenstein 2016), the European Union, nongovernmental organizations (NGOs), or immigrants (cf. Antal 2017). In this text, we focus on the ways in which Czech President Miloš Zeman uses the term security (and other related terms; see following sections), which leads to the creation of a populist framing of the issue of Islam and migration as security threats.

For $>20$ years, Miloš Zeman has without doubt been one of the most prominent figures in Czech politics. In the first half of the 1990s, he became Chairman of the Social Democratic Party, which he built up from a party with minimal preferences to one of the strongest political actors in the country and a party that repeatedly won elections at the end of the 1990s and beginning of the 2000s. Thanks to these successes, Miloš Zeman also became the head of the Czech Government from 1998 to 2002. After his failed candidacy for the presidential seat in 2003, when even members of his own party voted against him in an indirect election, he left the party as well as Czech politics in general After direct presidential elections were instated, Zeman (similar to other populists) began to profile himself as a nonpartisan candidate, advocating the interests of the people (cf. Mudde 2004). After a very negatively-toned campaign, which managed to polarize the Czech public (cf. Červinková and Kulhavá 2013), he became the third president of the independent Czech Republic in the second round of the historically first direct election in 2013. Equipped with a strong legitimacy stemming from the nation-wide popular vote, Zeman began to serve his function in office in a way that further polarized Czech society. Zeman actively intervened in political processes in a manner that did not correspond to a parliamentary regime or constitutionally determined powers (Brunclík and Kubát 2016), thus destabilizing the Czech political scene. Furthermore, immediately after his election, he became highly active in the media and granted interviews to daily tabloid newspapers, disinformation websites, or in his own television show. Throughout the course of his whole political career, Miloš Zeman has been known for generating strong statements often made on a personal level. He has handed out various labels to his political opponents, which have often been borderline or blatantly vulgar (which is typical of populism; cf. Tarchi 2016). Previously, during the direct election, he highlighted this system of elections with the argument that, contrary to politicians, the people are 
incorruptible. Even despite this populist rhetoric aimed at emphasizing the "common folk", Miloš Zeman is known for his rhetorical attacks on variously conceived groups of his real and assumed opponents (journalists, political opponents, or those who do not agree with his political style and opinions) that fall under the category of common folk. This has led a large portion of the Czech public to accept Zeman and left the remainder to spurn him. This can be perceived as another characteristic of populism (cf. Antal 2017).

According to the theory of populism (see following sections; Mudde 2004; Woods and Wejnert 2014), populist actors often use the issue of security to give labels to their political opponents and vaguely defined terms (such as migration, Islam, and so on, which in our concept is linked to security) (Bourbeau 2011; Androvičová 2015). The term security is used frequently in political and political science discourses and represents one of the most important categories of rhetorical and practical politics (cf. Lupták 2017) and its research. This is logical given the fact that one of the basic functions of the state is to ensure the security (however the term is defined) of its citizens and structures. For this reason, it seems relevant to look at the context in which this concept is dealt with and how it is handled by the Czech executive branch. It should be mentioned in the Introduction that we intend to follow the topic of security in its conventional sense, not in a broad sense (cf. Ušiak and Nečas 2011).

The aim of the text is to provide an interpretation of the ways in which Czech President Miloš Zeman constructs the content of the term "security" and how the content that is created in this manner figures in the framework of his rhetorical and actual political strategies. We focus on several particular mutually interlinked topics - primarily what, in Zeman's mind, are the causes and consequences of security (or danger), how threats should be further combated, and the intentions that Miloš Zeman has when mentioning security (or danger). According to Zeman's speeches, statements, interviews, and so on (see following sections), the issues of Islam and immigration are the most serious threats for Czech and European security. For this reason, we analyze how Miloš Zeman speaks about Islam and immigration as security threats via the optics of security. In order to deduce the research question that we have established, we used our theoretical concept of populism (see following sections), which is closely linked to the concept of security, the creation of a category of a people threatened by their enemies, and - in general - the securitization of various groups and phenomena. Due to this fact, we assume that our research design can be perceived as a contribution to the debate related to populism (Mudde 2004; Aslanidis 2016), securitization 194 
of migration (Bourbeau 2011; Androvičová 2015; Novotný 2017), and Islamophobia (Ostřanský 2018). The concept of Islamophobia in the Czech Republic is a relevant concept for our research because the target audience of Zeman's speeches "wants" to listen to such framing. Of course, this is in accordance with the theory of populism (Mudde 2004).

In regard to the fact that the President can be considered without doubt to be a moral authority or a "moral entrepreneur" (cf. Cohen 2011), the labels that he creates and introduces into dominant political and social discourse (in the sense of the imagination of how things should be - Chiapello and Fairclough 2002, p. 195) are a highly relevant topic of research. The Czech President (as an institution and a specific individual) has long held a high position in terms of public approval ratings carried out by the Public Opinion Research Centre under the Czech Academy of Sciences. For this reason, it can be assumed that the messages of the President are seen by a large portion of Czech society as "truth" or "objective reality", which is further mediated and amplified by the media (cf. Altheide 2002; Žúborová and Borárosová 2016). His reelection to a second presidential term in 2018 validated these tendencies.

This issue, or - more exactly - both of its elements (the President and security), show both high social, political and academic relevance. The analysis of presidential speeches has a strong tradition in political science (see Meernik and Ault 2013; Gregor and Macková 2015), which stems from the symbolic importance of the function on which certain expectations are based (cf. Scacco and Coe 2017). Through his speeches, the President creates certain narratives - in this sense, presidential speeches are understood as an integral part of the public sphere, which is also linked to the construction of the shape of democracy in a given country (Reisigl 2008).

\section{Populism, Islamophobia, and the Czech context}

For years, the issue of immigration has been woven into European political discourse as a red thread. The so-called "immigration crisis" represents a phenomenon that almost all relevant and even wholly marginal political parties feel the need to react to. This need is striking especially among entities that can be called populist. The Czech Republic in this respect is not an exception. The issue of migration is also linked to a number of areas that it permeates - migration is spoken of commonly in the context of either the economy (cf. Žúborová and Borárosová 2016), security (cf. Androvičová 2015; Bourbeau 2011), and identity or (in a wider context) religion, culture, and nation (cf. Czajka 2014). 
The debate regarding immigration is linked to practices of political populism not only in the Czech context. Empirical research on populism covers a relatively wide spectrum of analyzed actors - it ranges from the populist behavior of regimes as wholes (e.g., Antal 2017), political parties, movements, and interest associations (e.g., Mudde 2007) to the behavior of individuals (e.g., Hawkins 2009). The topic is also discussed in the Czech environment, where - in recent years - studies dealing with both the Czech (e.g., Stulík 2016 or Kaniok and Havlík 2016) and European (e.g., Novotný 2017) contexts can be found.

All of the fundamental texts dealing with populism agree on the fact that the "us" vs. "them" dichotomization (Barr 2009, p. 31; Sanders et al. 2017) is one of the key categories that populism deals with. In all these forms of populism, there is strong use of the concept of the endangerment of "us", i.e., "the people", by variously defined enemies such as corrupt political elites (Wolkenstein 2016), the European Union, supranational elites represented by e.g., George Soros, nonprofit organizations, or immigrants (cf. Antal 2017). Immigration is a matter that populists take strong stances on (Akkerman et al. 2014). From this, it is evident that the concept of "the people" is exceptionally vague, and the people are mostly understood in an exclusive, strongly nationalistic concept of nation. The category of "them" represents a threat to the people (which is another central principle of populism: Moffitt and Tormey 2014) and is directly linked to the nationalist concept of nation. The category of "them" is often linked to someone who is not a member of their own nation or is betraying it (e.g., "national elites serving Brussels"). If the people are threatened, the situation requires a nonstandard "crisis solution", de facto making it possible to circumvent standard democratic processes in the name of the security of the people (Antal 2017; Agamben 2008).

As the elections to the Chamber of Deputies in 2017 showed, the resistance against immigration and its link to the issue of security comprised the central topics of the elections. In terms of election discourse (Krčál and Naxera 2018), the connection between the topics of immigration and Islam is also evident. The significance of the issue of migration and endangerment by migrants can be demonstrated in the individual election statistics. From among a total of 31 subjects running for the election, almost half built their program solely upon the refusal of immigration or it was one of their strongest program points. These parties ran >2,200 candidates, which - in terms of the proportion between the number of accepted asylum applications from the beginning of the year to the end of 2017 (which was 125 including subsidiary protection) - makes up a ratio of 18 candidates for every asylum seeker. Although the 
vast majority of these parties was wholly unsuccessful, and the total number of votes gained by the majority of parties was only $>2 \%$, this rhetoric used by the extremist-populist party (cf. Alvares and Dahlgren 2016) Freedom and Direct Democracy - Tomio Okamura (FDD) created the fourth strongest entity in the Chamber of Deputies after gaining a total mandate of 22 seats. At the same time, topics relating to the nation, immigration, and Islam (which is an important analytical category in the Central European context often linked to these issues) appeared in the programs of other successful political parties along the whole spectrum of right to left ideology intersecting the whole Czech party system (more generally, cf. Mareš et al. 2015). As previous research shows, the ANO movement, which was the clear victor in the elections, used the topics of immigration in a similar manner (which was, however, different from that of FDD). FDD and ANO, who use purely populist anti-immigration rhetoric during elections (Krčál and Naxera 2018), occupied a total mandate of half of all seats. This both shows the effectiveness of populist strategy, which lies in creating an image of the enemy, and is proof of the support of this discourse by a significant portion of Czech society.

Even despite the fact that only a strong minority of all the aforementioned number of asylum seekers (or foreigners in the Czech Republic, in general) are people from predominantly Muslim countries and Czech society has no negative experience in cohabiting with Muslims or with their possible radicalization, Islam in Czech public discourse is linked to immigration to such a degree that the terms "immigrant" and "Muslim" (or "terrorist") are linked on an almost synonymous basis (for more details, see Ostřanský 2018). This synonymous concept appears not only in public discourse but also in the discourse of the political elites. This is evident from both the analysis of the election programs of Czech parties (cf. Krčál and Naxera 2018) and the analysis and interpretation on Zeman's operationalization of the term security. Based on the whole corpus of data and the context of Czech politics, we can allude to the fact that if Miloš Zeman speaks of the threat of immigration, he also implicitly means the threat of Islam.

\section{Data and methodology}

Methodologically speaking, this paper has been conceived as a computerassisted qualitative data analysis (CAQDAS) of a data set, which is made up of complete interviews, statements, speeches, and other expressions made by Miloš Zeman in his first presidential term (March 2013-March 2018). All documents were taken from the official website of the President of the Republic (http://www.zemanmilos.cz/cz/; all texts are available in the Czech language). 
The total extent of the data set is 730,192 words. The data set was processed using MAXQDA11+ software (cf. Oswald 2017) while using the extended lexical search method. The search subject included words that are linked to the phenomenon of security, namely, security/danger, endangerment/endanger, threat, and risk. The found occurrences were subjected to manual refining. During this refining process, occurrences of terms that 1 ) were not linked to the topic of security (e.g., "securing [in the sense of providing conditions for] the course of the event") and 2) were not linked to the conventional concept of security but fell into the wider concept of it (e.g., "ensuring the security of miners") were deleted (cf. Buzan et al. 2005). After refining, we identified a total of 320 codes, i.e., the results of the keyword search. We used the standard procedure of inductive coding achieved via specialized software (see Saldana 2009). On the basis of inductive coding, we then divided the found codes into several subcategories. This is linked to the fact that the size of the data corpus allows us to follow the contexts in which the actor operationalizes the issue of security, what purposes they have for speaking about it, and what reasons they have for using this topic. Based on this idea, we are able to interpret several varying methods for dealing with the issue of security (although codes may overlap in many cases). Our approach can thus be called hermeneutic (see Ricoeur 1981).

Our effort is to show Miloš Zeman's perception of Islam and immigration in the whole context of (in)security. For this reason, we dealt with the President's perception of security in general. The code tree (see Fig. 1) begins with operationalization of the term security (a total of 15 occurrences) and then determination of the sources and causes of the state of "danger" - in this category, there were uses of terms that imply a potential risk, threat, and so on (a total of 130 codes). The third coding category is made up of statements that relate to actors ensuring security and is more or less the opposite of the previous category (a total of 29 codes). The fourth category naturally works off the previous one and is devoted to the specific methods and practices via which security is to be ensured (a total of 86 codes). The final category is linked to the use of terms in the sense of delegitimizing labels. These are statements that Miloš Zeman uses to attack various actors and primarily his symbolic adversaries by pointing out various aspects of security (a total of 60 codes). This method of argumentation (using a delegitimizing label) can be considered a standard style of behavior among populist politicians, which is linked to the populist reduction of politics into a "battle against a vaguely defined enemy" (cf. Moffitt and Tormey 2014; Antal 2017). 
Handing out delegitimizing labels and, on a general level, securitization or the creation of images of the endangerment of "us" by "the others", regardless of whether this is a "realistic" threat, are other typical signs of political populism. The methodological approach we have chosen and its implementation (i.e., the method of coding) are directly linked to our selected theoretical perspective, which traces the principles of political populism.

From our perspective, it is evident that we have decided not to seek out and analyze all of Zeman's statements on Islam, Muslims, or migrants, but only those that are linked to the issue of security. This provides an analytical framework for the President's view on Islam and migration. The design of our analysis stems from the tradition of interpretative political science (see Bevir and Rhodes 2016), so our effort did not aim to find causality or provide explanation for the analyzed phenomenon. We tried to put forward an interpretation based on transparency of our procedures and arguments.

Figure 1: Structure of the code tree.

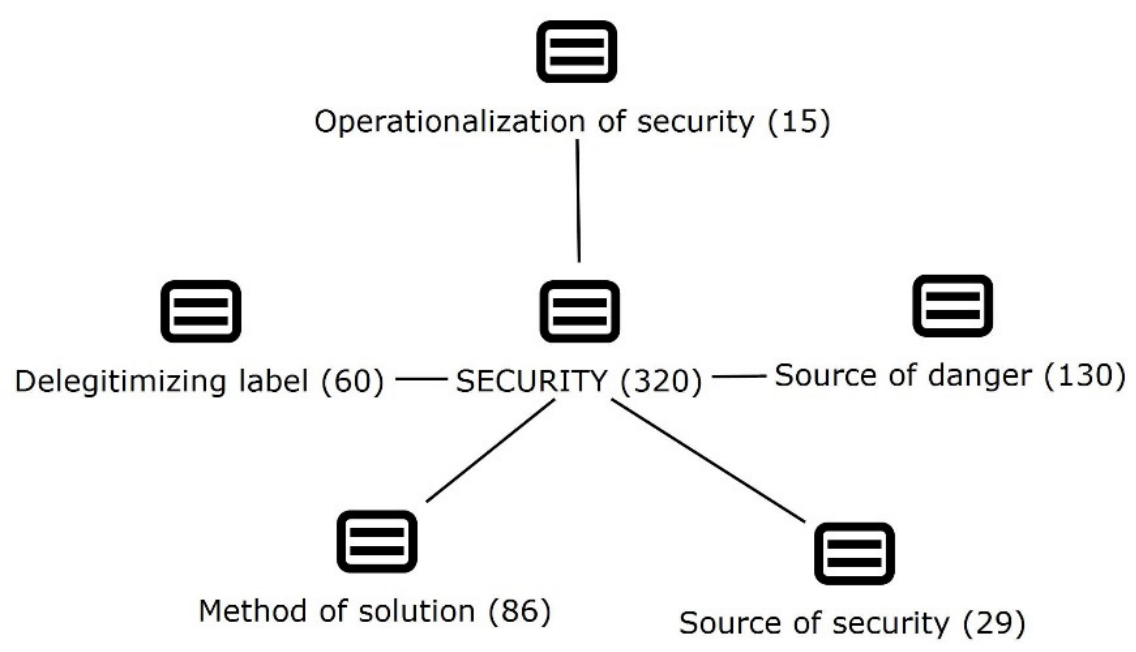

Source: The authors.

\section{Operationalization of terms}

We begin with how Miloš Zeman perceives the essence of security. In his view, security is a crucial matter: "The national interest of every state has three parts. First, there is security, second there is economic growth, and third there is social stability or - if you like - social compromise." In order to ensure security, however, it is important to realize the possible existence of threats and risks: "We assume that we live in a society that is endangered by almost 
nothing and that is a great mistake." That is why it is necessary to continually point out possible risks (cf. Foucault 1983): "Apprehension is different than fear. Apprehension from a danger is sensible." "A person who has warned of a real danger is more likely to draw attention and stand the test than a person who has closed his eyes to this danger. So, history will have to be the judge of whether the refugee crisis was a realistic danger to Europe or not." It is evident in this quote that, in the context of contemporary Europe, Miloš Zeman sees Islam and the so-called migration crisis (see following sections) as fundamental dangers. Here, it is evident that Zeman sees the source of the endangerment of pure people (Mudde 2004) as migration and the influx of Muslim migrants that it is linked to.

The last quote shown in the previous paragraph also shows that two coding categories overlap in one statement, which is a wholly common phenomenon in inductive coding. First, Zeman operationalized the essence of security ("it is necessary to point out dangers") and, at the same time, communicated the source of the danger ("the refugee crisis") while also offering a method to solve it (to be watchful and point out possible danger). There have been more such overlaps in the text. The mutual co-occurrences of code categories are shown in Fig. 2, in which a large overlap is evident between the categories of "source of danger" and "method of solution" - in addition to designating risk factors, Zeman thus very often also presents his vision of how the given problem should be solved. This statement can serve as an example: "I would appreciate if the Czech Army took part in the additional guarding of the European Union's borders, which have hitherto been reprehensively unprotected against the influx of illegal migrants who do not respect international agreements, are not applying for asylum in the first safe country as the Dublin Regulation requires, and are crossing multiple borders and by doing so are committing an act of illegal migration." Migration and the insufficiently guarded borders of Europe represent the source of danger; the solution to the problem is to involve the Czech Army.

A second common overlap can be found between the "source of danger" and the use of "delegitimizing labels" - it is evident that Zeman uses the topic as a discursive practice via which he attempts to damage selected actors whom he semantically links to the source of danger or the inability to prevent it. The following statement is an example: "I see the danger [...] of dividing society primarily in the risk of labeling. That is to say that every person who is afraid of this wave of migration, primarily from Islamic countries, can be labeled a xenophobe, racist, or even a fascist." In Zeman's view, people who criticize the opponents of migration thus present a threat. In this statement, he also 
delegitimizes them (as, in reality, these are often the people who stand against Zeman). The next example of overlap is found in the following quote: "The European Union is forcing us to accept so-called refugee quotas, and the Czech government is justifiably objecting to the fact that accepting several thousand, for example, Syrian refugees would create the risk that among them will be jihadists and the relatively peaceful Czech Muslim community will begin to radicalize." The sources of danger are jihadists hidden in the wave of migrants; at the same time, the EU and its redistribution system are delegitimized.

Figure 2: Mutual co-occurrence of codes.

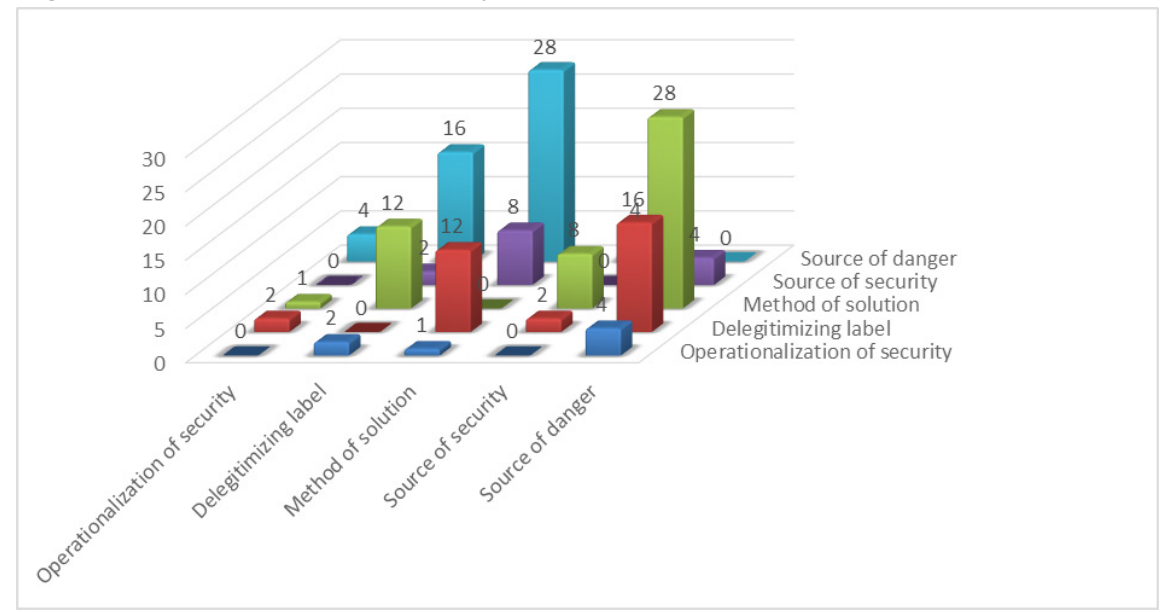

Source: The authors.

\section{The source of danger}

If we read the individual codes relating to Zeman's understanding of what the source of danger is, we find one central theme that is linked to Islam, Islamism, jihad, migration, terrorism, and so on (cf. Kosárová and Ušiak 2017). This topic clearly dominated in Zeman's speeches. In the beginning of his presidential mandate, it was possible on several occasions to find other topics - e.g., Russia as a security threat considering the conflict in Ukraine (e.g., "We see the situation in Ukraine and what threats exist there, that is, a certain reinstallation of Russian power that had been somewhat forgotten."). Over the course of time, however, he began to relativize the issue of Russia and finally ceased to talk about Russia as a source of danger altogether ("I refuse the opinion that there is danger in the East."); he did, however, begin to emphasize the threat of migration and Islamic terrorism ("I have long 
contended that these attributes are endangered by Islam, primarily by its radical branch, which has several times declared its intent to conquer Europe and subject it to its own culture."), which he explicitly placed above the "Russian problem":

Decades ago I had already realized that individual nation states are exposed to external danger. At that time, I saw Russian imperialism as the primary danger. Well, it turned out that the real enemy wasn't forming to the east, but to the south in the form of the Islamic State and its branches such as the Taliban, Al-Qaeda, or the Muslim Brotherhood. In the meantime, the number of these organizations has grown considerably. Sometimes they fight amongst themselves, because - as Charles Darwin wrote - the greatest aggression is of an internal nature. On the other hand, they are willing to unite in the interest of creating one Islamic State, a caliphate.

Zeman contextualizes Islam/migration as a source of danger on several levels. First, it is a potential source of terrorism:

The danger has come closer to our borders and, by the way, it is naïve to assume that there is no connection between the wave of migration and terrorism, because that would mean assuming that this wave of migration does not include potential jihadists, the number of which we naturally cannot estimate precisely, but some of them [...] have taken part in the Paris attacks mentioned previously.

Over Europe "looms an enemy, international terrorism based on hateful ideology that is in a way very similar to the ideology of Nazi Germany." According to Zeman, Western civilization is at war with this extremist enemy. This war "is already in full swing and is not a "cold" war [...] but a truly "hot" one. It is a battle with the Islamic State. It is being led with the use of modern weapons including drones, satellite espionage, and so forth. The extent of this war is growing before our eyes, and therefore additional extremist organizations such as Boko Haram and others are scrambling toward the front together with the Islamic State. I would say that this is a religious war. Something similar happened in Europe in the Middle Ages when a clash between Catholics and Protestants took place. Now it is the confrontation of militant Islam with the rest of the world."

In terms of migrants, Zeman repeatedly mentions their illegal behavior: "The term refugee evokes various associations within us, but in reality these are people who have continually broken the law by not applying for asylum in the first safe country." According to Zeman, empathy with refugees itself is a problem. The President does not see these individuals as real refugees, but as invasive armies: "Through their [i.e. politicians] indecisiveness and a number 
of other seemingly conciliatory and seemingly humanitarian gestures, which in my opinion do not appreciate the true danger, because, contrary to them, I see the migration crisis as an organized invasion." Zeman sees manifestations of Islam as such as a source of danger: "I have made the objection - and this is linked to religion - that Islamic migration is dangerous because it is not possible to assimilate it into European culture." "[...] it's not possible to carry on a discussion with the Islamic State; it's not possible to debate with those who, like a social cancer, want to destroy existing civilizations. If we are going to close our eyes in our discussions and say that they're all peaceful and they want to cooperate, then it will be too dangerous. Because anti-civilizations are destroyed with weapons and not dialogues." Miloš Zeman further developed the metaphor of social cancer when he stated that the "Islamic State is thus something like cancer. But this isn't a tumor. Many cancers have metastases, which are far more dangerous than the tumor itself. Therefore we can observe the spread of radicalism, terrorism, and fanaticism; and we must ask ourselves: how much longer will we wait? How much longer will we commiserate? How much longer will we merely express our solidarity? “

Islam and migration influence the security situation in Europe in yet another way: "The second risk is extremization or, if you will, the radicalization of the population, which is for now calm and stable. Alright, I'll give you one unpleasant example. In the 1930 s, a calm and stable population lived in Germany. It was a very cultivated population, a nation of Goethe and Schiller. Over the course of a few years, this cultivated nation became a group of fanatic Nazis. Over a mere several years. We must concede that such radicalization and extremization is possible even today." The wave of migrants is thus the source of the security risk both because of potential terrorists and also as a source of radicalization and extremization of the European population (Krčál 2017).

If we were to quantify a result from the 130 codes found and in which Zeman discusses the source of danger, 95 (i.e., three-quarters) deal with issues of immigration, Islam, or Islamic terrorism, which are (according to Zeman) closely related. Mention of other types of danger (primarily Russia) have appeared only in roughly the first year of his mandate; over the course of 4 years, Zeman mentioned other sources of danger sporadically and only in single-digit occurrences. Thus, Zeman's concept of the sources of danger has been evidently monothematic in the past years. 
Table 1: Sources of danger

\begin{tabular}{|l|l|l|}
\hline $\begin{array}{l}\text { THREAT is } \\
\text { represented by }\end{array}$ & RUSSIA & Imperialism (later marginalized) \\
\cline { 2 - 3 } & ISLAM & $\begin{array}{l}\text { Extreme enemy; in contradiction to } \\
\text { Europe culture; it cannot be assimi- } \\
\text { lated; associated with immigration }\end{array}$ \\
\cline { 2 - 3 } & IMMIGRATION & $\begin{array}{l}\text { Source of terrorism; invasion to } \\
\text { Europe; radicalization of European } \\
\text { society; associated with Islam }\end{array}$ \\
\hline
\end{tabular}

Source: The authors.

\section{The source of security}

In addition to factors that represent sources of danger, Miloš Zeman also thematizes the opposite pole or, in other words, he builds semantic constructions of what can be labeled a source of security. The first is the army, both the national army and the one that is built on a higher level: "In terms of security, I am convinced that security elements in the European Union should be strengthened with the long-term prospect of a European Army." The Army of the Czech Republic should actively take part in the fight against terror side by side with the armies of other states. The second source of security is made up of multinational organizations: "The fact that the Czech Republic is a member of both groups, that is, the European Union and NATO, gives us the guarantee of security." "I am deeply convinced that the EU - but also NATO - are tools that cannot nullify the risk of war, but they can reduce it." This involves not only membership but shared actions: "You know that I'm speaking of the wave of migration that has hitherto and only hitherto avoided us but has significantly impacted our neighboring countries. I appreciate the fact that our army is prepared for this new danger. I appreciate the exercises that have recently taken place in cooperation with the police in South Moravia and I appreciate the offer that the Czech Republic has made to Hungary and recently to Slovenia in sending soldiers and police officers to support the protection of their borders."

In the context of the so-called migration crisis, other bodies, armed and unarmed, can represent a source of security: "I believe that, if various cautionary prophecies are fulfilled - and no one wants them to be fulfilled the army, police, and even the fire and rescue teams will have their hands full in dealing with the dangerous wave of migration." 
Table 2: Source of security

\begin{tabular}{|l|l|l|}
\hline $\begin{array}{l}\text { SECURITY } \\
\text { is provided by }\end{array}$ & $\begin{array}{l}\text { ARMY (IN THE CASE OF } \\
\text { CRISIS, ALSO POLICE, FIRE } \\
\text { AND RESCUE TEAMS) }\end{array}$ & $\begin{array}{l}\text { Fight enemy home } \\
\text { and abroad }\end{array}$ \\
\cline { 2 - 3 } & $\begin{array}{l}\text { INTERNATIONAL ORGA- } \\
\text { NIZATIONS (NATO; EU) }\end{array}$ & $\begin{array}{l}\text { Common actions } \\
\text { and training }\end{array}$ \\
\hline
\end{tabular}

Source: The authors.

\section{Method of a solution}

We can fluently link Zeman's concept of the ways in which security should be achieved to recognizing security threats and determining the actors that should provide security. The methods for dealing with the issue logically stem from the way Zeman understands security. In other words, these methods are fixed on the question of Islam. The first is the active use of the army, including foreign missions: "[...] I can say with full certainty that our soldiers are fighting in Afghanistan for our security." Engagement abroad, however, is not meant to be the unilateral actions of individual states; the whole international community should be taking part in the fight against terror: "I would like to emphasize something that is rarely emphasized: Firstly, the attacks against the Islamic State cannot be a unilateral action - they must be an action under the aegis of the UN Security Council, because superpowers lead many, many conflicts, but they have one shared enemy - Islamic terrorism." The West should cooperate in this regard with Russia: "Not long ago I exchanged letters with President Putin concerning the preparation of an anti-terrorist resolution in the UN Security Council because I will be visiting the General Assembly again."

A coordinated approach on the part of different states is necessary on European soil, primarily in securing the EU's external borders ("So far, the European Union has shown zero ability to protect its external borders.") and in enforcing the so-called Dublin Regulation, which - according to Zeman - has been repeatedly violated, heightening the risk for the Czech Republic: "My opinion is quite simple and based on valid international agreements, according to which refugees should apply for asylum in the first safe country that they enter and that is definitely not the Czech Republic. Each refugee in this respect is violating international law and committing a criminal act. As a sovereign state, we have the right to send the army and police to the borders and prevent these people - who are $90 \%$ young men, with an iPhone in one pocket and Euros or dollars in the other - from entering into the interior 
and having to be detained in detainment facilities. If we want to protect our culture, if we want to protect our customs, if we don't want to take the crosses down from our walls if we have them there at all, and to ban pork and other such things, then we should find the courage to protect the sovereign state that is the Czech Republic.

In addition to closing borders, Zeman claims it is necessary to deport some people who have come to Europe: "Should security forces or the whole EU strongly react to this by closing its borders or possibly deporting these people back to their original countries? Everyone should live in their original country. It's one thing to travel and meet new cultures and another to live in your own country and work in its favor. I think these people should live in their own countries, practice their own religion, and not try to disrupt normal life in countries where there is a different culture. Their countries of origin are not however Algeria, Mali, Libya, but France, Germany, Britain, or Sweden where their parents were born."

One of the suggested solutions for this endangerment is thus a direct battle with the representatives of Islamic fundamentalism, which Miloš Zeman repeatedly emphasizes: "You know that for several years now I have been calling for a war against radical Islamism. You know that war is not meant to be a war of words, but a war of actions. And a war of actions specifically means - and I said this recently in Warsaw at the NATO summit - what good is NATO to us when it's not able to use armed force to intervene in Southern Europe in the fight against the Islamic State?" The next method of dealing with this problem is thorough work in the selection of migrants and possible deportation of such elements that could - in the domestic environment - serve as a source of Islamic fundamentalism. This strategy is visible in Zeman's stance on the aforementioned quotas on the acceptance of refugees on the part of the European Union. In this context, Zeman stated that "the European Union is forcing us to accept so-called refugee quotas and the Czech government is quite justifiably objecting, saying that accepting tens of thousands of, for example, Syrian refugees could present the risk that, along with them, some jihadists may come with them and the relatively calm Czech Muslim community would begin to radicalize. On the other hand, however, we must have an understanding for this request of the European Union. This understanding may, for example, be expressed by providing solidarity aid to the countries where refugees are located. [...] This is still better than having refugees on our own territory." "I'm not saying that we should refuse immigrants, I'm saying that we should refuse both illegal immigrants and Muslim immigrants. Mr. Prime Minister assumes that we 
should not accept them based on mandatory quotas but on a voluntary basis. Which, to be honest, is the same thing. In an extreme case, we could accept even more than the mandatory quotas require from us." If a source of Islamic fundamentalism happens to appear on the territory of the Czech Republic, Zeman sees it necessary to resort to deportation. "Why not deport radical groups that spread terrorism and prepare acts of terrorism or invoke terroristic psychosis through their hateful propaganda?" "I assume that, similarly to Britain's expulsion of radical imams, every country has a right to eject people suspect of organizing acts of terrorism".

The method of ensuring security is also rooted in the direct engagement of citizens who own weapons. In this respect, the President (similarly to, for instance, the former Ministry of the Interior, Milan Chovanec) has criticized the EU's plan to limit the possibility to possess certain types of weapons: "You know, this would be a somewhat one-sided armament in a situation where the risk of terror attacks is growing. Of course if terrorists didn't exist and there were only crazy murderers firing sometimes legally and sometimes illegally held weapons, then the situation would be different; in that case I wouldn't mind restricting the possession of firearms. But, there's a new situation here the police can't watch all the clubs, whether that's in Paris or elsewhere, and so the principle of self-defense applies." Thus, a method of dealing with the security problem in Zeman's view is that each person should face the problem, even if that means doing so with a gun in his or her hand. ${ }^{2}$

It is evident from these suggested solutions that a number of them surpass the boundaries of standard procedures and solutions to political problems in terms of the liberal-democratic order. This wholly aligns with the previously outlined theoretical assumption of populism - the interest of populists is to create a notion of a permanent state of endangerment that can help them legitimize their steps leading outside the boundaries of their legal authority and beyond the framework of a democratic system in the name of securing the safety of the people (Antal 2017; Agamben 2008).

2 Here, we can mention a microtopic that Zeman speaks about relatively often and which is, in his interpretation, strongly linked to the issue of Islamic terrorism in Europe. Zeman has repeatedly praised the fact that, after several terrorist attacks in Europe, the seat of the President, Prague Castle, has been equipped with security gates that thousands of visitors must pass through. According to Zeman, the visitors are satisfied with the measures: "So, on the contrary, they saw at it as a pleasant matter, and just about all of the visitors said they feel safer now in the castle complex." In this context, however, the President was facing criticism from a number of security experts, who claimed that establishing security gates will reduce the speed of entrance into the site, creating lines of people that could serve as an ideal target for a potential attack. 
Table 3: Solutions

\begin{tabular}{|c|c|c|}
\hline \multirow{9}{*}{$\begin{array}{l}\text { THREATS } \\
\text { should be } \\
\text { solved by }\end{array}$} & \multirow{5}{*}{$\begin{array}{l}\text { PROVIDING SE- } \\
\text { CURITY }\end{array}$} & Multilateral army actions \\
\hline & & Cooperation with Russia \\
\hline & & War against radical Islam \\
\hline & & Refusal of Muslim immigrants \\
\hline & & Citizens armed with light weaponry \\
\hline & \multirow{4}{*}{$\begin{array}{l}\text { REDUCING THE } \\
\text { NUMBER OF IM- } \\
\text { MIGRANTS }\end{array}$} & Refusal of Muslim immigrants \\
\hline & & $\begin{array}{l}\text { Control and defense of } \\
\text { European borders }\end{array}$ \\
\hline & & Deportation of illegal immigrants \\
\hline & & $\begin{array}{l}\text { Providing help in the } \\
\text { places of conflicts }\end{array}$ \\
\hline
\end{tabular}

Source: The authors.

\section{The delegitimizing label}

The last coding category is linked to the use of the security phenomenon in order to hand out negative labels (usually to Zeman's political adversaries or symbolic enemies). This use of the term security is the only one in which we find a number of examples of security (or danger) not being related to the issue of Islam. ${ }^{3}$ The first interesting category of delegitimizing label is linked to the EU and its relationship with Russia, which aligns with the abovementioned statement that Zeman made in regard to Russia. Zeman began to actively criticize the EU for its sanctions against Putin's regime, which he sees as futile and counterproductive. Another example of the delegitimization of the EU can be found in the following statement: "I see a large risk of terrorist attacks in Europe and the Czech Republic, but I think this chatter about various cybernetic attacks is just a fad." By saying this, Zeman is trying to defend Russia, which is seen in Europe as the source of hacking attacks on European

3 Zeman, on many occasions, has mentioned the topic of security in connection with his Chancellor, Vratislav Mynár, not being awarded a security clearance by the National Security Authority (which can be understood as a possible threat to security when an individual without a security clearance works at such a high position). Zeman's only reaction, however, was the repeated delegitimization of the National Security Authority, which "[...] works quite miserably." Zeman then used this topic pragmatically to delegitimize another one of his adversaries: "If I remember correctly, for example, Mr. Schwarzenberg, President Havel's first chancellor, also lacked a security clearance." In 2013, Karel Schwarzenberg ran against Zeman in the high-tension presidential elections and was, at the same time, chairman of the TOP09 party, which was Zeman's primary critic on the floor of the parliament. 
states. Zeman depreciates the problem and draws attention away from it toward the issue of Islam and migration.

Additional efforts to delegitimize the EU are linked to the issue of the socalled migration crisis. For example, Zeman has repeatedly said about EU quotas for the division of refugees that: "Europe is forcing us to accept the socalled refugee quotas and the Czech government is quite justifiably objecting, saying that accepting tens of thousands of, for example, Syrian refugees could present the risk that, along with them, some jihadists may come with them and the relatively calm Czech Muslim community would begin to radicalize." The issue of migration is also linked to the effort to delegitimize a number of other actors connected to this topic (for instance, journalists, who have long been one of Zeman's favorite targets): "I think the world will realize the danger of radical Islam the moment these attacks cease to take place outside Europe and the USA and start to affect people who create public opinion, which in this case are journalists." By saying this, Zeman is not just delegitimizing journalists, who in his eyes do not sufficiently refer the threats linked to Islam, but all members of society who are not succumbing to a shared moral panic (cf. Cohen 2011). "I think that it's naturally convenient for those who want to endanger Europe just as they've done in the past with intolerant fanaticism if Europe is unarmed and I hold the opinion that, as we have for example experienced Nazi expansion, the Nazis' biggest allies were the pacifists." In the Czech environment, individuals who do not share Zeman's critical approach on immigration or Islam are labeled "welcomers" (i.e., those that welcome migrants, refugees, and so on) by the President and other actors (and also de facto by mainstream society). All delegitimized targets are linked together by the fact that they fall into Zeman's idea of what society or politics should not be like.

Table 4: Delegitimizing label

\begin{tabular}{|l|l|l|}
\hline $\begin{array}{l}\text { ACTORS } \\
\text { DELEGITIMIZED } \\
\text { BY LABELS OF } \\
\text { (IN)SECURITY }\end{array}$ & $\begin{array}{l}\text { EUROPEAN } \\
\text { UNION }\end{array}$ & $\begin{array}{l}\text { Increase of risk of terrorist attacks } \\
\text { by acceptation of immigrants }\end{array}$ \\
\cline { 3 - 3 } & Sanctions against Russia \\
\cline { 3 - 3 } & $\begin{array}{l}\text { Forcing the Czech Repub- } \\
\text { lic to accept immigrants }\end{array}$ \\
\cline { 2 - 3 } & JOURNALISTS & $\begin{array}{l}\text { Provide false informa- } \\
\text { tion about immigration }\end{array}$ \\
\hline
\end{tabular}

Source: The authors. 


\section{Conclusion}

It is obvious from the text that Miloš Zeman's "topic number one" in regard to security is Islam, as well as the concepts of immigration, Islamism, terrorism, and so on that are linked to it. However, it should be said that Zeman does not differentiate much between these terms in his speeches and creates an implicit link (or, in some cases, an "equal sign") between them. When he speaks of the danger of immigration, his messages implicitly contain the concept of the threat of Islam. Although in the beginning of his presidential function, he labeled Russia as a security problem on several occasions, he later reframed this point of view, relativizing the issue of Russia (in connection with events in Ukraine) and ultimately denying it completely. It may be added that Zeman reached the peak of this approach in October 2017, when he de facto acknowledged Russian annexation of Crimea in a speech on the floor of the Council of Europe. After Zeman ceased to thematize Russia as a source of danger, Islam - as a whole - remained in his view of security issues for the Czech Republic and Europe as the only threat worth mentioning (any mention of other sources of danger were wholly incidental and inexplicit in Zeman's speeches - e.g., the statement that a source of danger "might be propaganda").

The way in which Zeman refers to Islam as a threat targets the very roots of this faith, which is understood as something wholly incompatible with Europe and its culture. Thus, it is not only radical Islam and the terrorism connected to it that are problems and security issues; it is also Islam as such. This concept of the endangerment of security is then linked to suggested methods to remedy the situation, which - in the majority of cases - are aimed at the fight against Islamic organizations or preventing immigrants from stepping onto European (and thus Czech) soil.

The primary connection to the academic debate concerning populism can be seen along several lines. The first is the original and hitherto-unprocessed data that deal with a significant actor. Our approach, methodology, and the data used have allowed us to record the phenomenon in question in its entirety. Thus, this is not an analysis of individual statements, but an analysis of the logic of the whole discourse formed over the course of the 5 years of the President's mandate. This makes it possible to interpret the manner in which the reference point, i.e., the threat (in our case, the shift from Russia to Islam), is transformed. The second is the link between the topic of populism and the issue of security, which has stood at the center of our interest. Based on a framework established as such, we have shown the ways in which Zeman makes use of the category of security as a tool of populist 
political strategy (cf. Moffitt and Tormey 2014; see Fig. 3). In terms of the way Zeman operates with security, populism is evident in several regards. The first is the way in which Zeman conceptualizes the threats themselves. In this regard, Ernesto Laclau's (2005) "empty signifier" may be applied. In Zeman's approach, the categories of "migration" and "Islam" are simplified (or even empty) categories labeling the "enemy of pure people", which is a central point of populist strategies (Mudde 2004). In terms of Zeman's use of these concepts, he uses the reproduction of stereotypes, various clichés, and simplifications ("young men with iPhones hiding behind small children"). The "us vs. them" dichotomy stemming from the collective concept of moreor-less homogenous and opposite groups is also evident. ${ }^{4}$ Strong statements that are conceived in this manner and are typical of populist behavior (cf. Tarchi 2016, p. 102) can be found in the category of solutions that are full of similarly conceived proclamations ("deportation/refusal/rejection of Muslim refugees", "combat", "war", and so on). Even these declarations are based on a simplified concept of an "enemy of the people". In the context of social science as a critical science, it can be stated that, in regard to security, Zeman often uses a method of argumentation and rhetoric that can be labeled to say the least - controversial and problematic. In Zeman's case, however, these intentionally strong statements aimed at splitting society are nothing new. Although Zeman repeatedly criticizes his opponents for dividing Czech society by handing out labels (such as "fascist", "racist", and so on), he does the same himself in relation to the term security - he hands out labels to his opponents, which mark actors as responsible for causing a potentially dangerous situation, intentionally dividing society. By emphasizing Islam as a threat, Zeman provides campaign support for the political formations that support him and are, in some cases, seen as extremist parties.

Hostile discourse that is construed in such a way and is linked to the concept of politics as an irreconcilable battle against enemies of the people (Antal 2017) is used by the analyzed actor to stigmatize other actors who are not always primarily linked to the issue of security in all regards. This also deals with actors who have long been the subject of Zeman's rhetorical attacks (the $\mathrm{EU}$, journalists). Due to a populist simplification of the concept of politics as a battle, these actors can also be presented as enemies of the people who are linked to endangerment on the part of migration and Islam. By taking a stance

\footnotetext{
4 One of the groups is defined by a religious framework ("Muslims") and stands in contrast to the "us" group (i.e., Czechs/Europeans), which remains unidentified. It is only clear that "our culture" stands in contrast and is endangered by "their culture", which fulfills the prerequisites of the theory of populism (Tarchi 2016) and can, thus, lead to the strengthening of Islamophobia in society.
} 
against these actors, Zeman is building his image of a protector of the people. As we have shown earlier, Zeman's suggested measures aimed at "protecting the people" often go beyond the boundaries of the norm that is standardly accepted in a democratic system. The effort to create an exceptional state of affairs meant to legitimize nondemocratic steps in a hitherto-democratic regime in the name of protecting the people is typical of populism (Antal 2017; Agamben 2008). In regard to Zeman's position as an influential moral entrepreneur (cf. Becker 1963) and his simplified portrayal of Islam, Zeman can be considered an actor that spreads Islamophobia in Czech society via the media (cf. Ogan et al. 2014). The statements made by Zeman (and other similar actors in Czech politics) are shared by a large portion of Czech society. In light of the symbolic capital of this actor, Islamophobic social attitudes, which were hitherto understood as a matter of marginal ideological streams, are legitimized and placed in the position of mainstream society, which in turn has support in the highest levels of politics.

Figure 3: Structure of Zeman's perception of security (in relation to Islam and immigration).

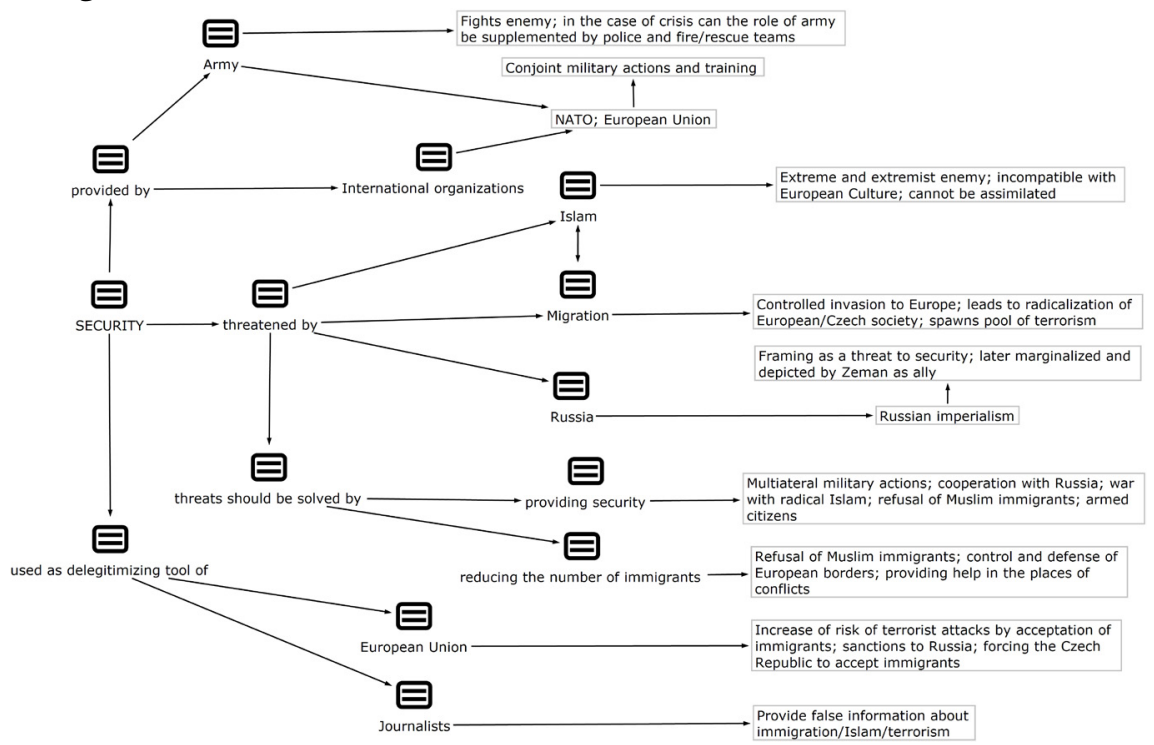

Source: The authors.

5 This was evident in terms of the election campaign for the presidential elections in 2018 just before the second round, when the country was flooded with billboards with inscriptions directed against Zeman's countercandidate Jiří Drahoš, who was purposely placed in the role of the "migrant welcomer" (despite the fact that Jiří Drahoš repeatedly expressed stances against accepting migrants to the Czech Republic). Next to Zeman's photograph, the billboards' inscription read "Stop immigrants and Drahoš. This is our country. Vote for Zeman!" Even this short text fulfills the criteria of populism in all respects (Antal 2017). 


\section{Acknowledgments}

This text was supported by the Institutional Support for Long-term Conceptual Development of a Research Organization, 2018, of the Department of Political Science and International Relations of the Faculty of Philosophy and Arts, University of West Bohemia, Pilsen, Czech Republic. Individual results of research have already been presented in the form of a conference paper (Naxera and Krčál 2018).

\section{References}

Agamben, Giorgio. 2008. State of Exception. Chicago: University of Chicago Press.

Akkerman, Agnes, Cas Mudde, and Andrej Zaslove Andrej. 2016. "How Populist Are the People? Measuring Populist Attitudes in Voters." Comparative Political Studies 47 (9): 1324-1353.

Altheide, David. 2002. Creating Fear: News and Construction of Crisis. Piscataway: Transaction Publishers.

Alvares, Claudia, and Peter Dahlgren. 2016. "Populism, extremism and media: Mapping an uncertain terrain." European Journal of Communication 31 (1): 46-57.

Androvičová, Jarmila. 2015. "Sekuritizácia migrantov na Slovensku - analýzy diskurzu." Sociológia. Vol. 47, No. 4.47 (4): 319-339.

Antal, Atilla. 2017. “The Political Theories, Preconditions and Dangers of the Governing Populism in Hungary." Czech Journal of Political Science 24 (1): 5-20.

Aslanidis, Paris. 2016. "Is Populism an Ideology? A Refutation and a New Perspective." Political Studies 64 (1S): 88-104.

Barr, Robert R. 2009. "Populist, outsiders and anti-establishment politics." Party Politics 15 (1): 29-48.

Bevir, Michael, and R. A. W. Rhodes, eds. 2016. Routledge Handbook of Interpretive Political Science. London and New York: Routledge.

Bourbeau, Philippe. 2011. The securitization of migration. A study of movement and order. London: Routledge.

Brunclík, Miloš, and Michal Kubát. 2016. "The Czech Parliamentary Regime After 1989: Origins, Developments and Challenges." Acta Politologica 8 (2): 5-29.

Buzan, Barry, Jaap de Wilde, and Ole Wæver. 2005. Bezpečnost: Nový rámec pro analýzu. Brno: Centrum strategických studií.

Červinková, Monika, and Lucie Kulhavá. 2013. "Karel Schwarzenberg a Miloš Zeman: Pozitivní a negativní kampaň k prezidentským volbám.” Naše společnost 2: 16-29.

Chiapello, Eve, and Norman Fairclough. 2002. "Understanding the New Management Ideology: A Transdisciplinary Contribution from Critical Discourse Analysis and New Sociology of Capitalism." Discourse \& Society 12 (2): 185-208.

Cohen, Stanley. 2011. "Whose side were we on? The Undeclared Politics of Moral Panic Theory." Crime, media, culture 7 (3): 237-243. 


\section{Journal of Nationalism, Memory \& Language Politics 12(2)}

Czajka, Agnes. 2014. "Migration in the Age of Nation-State: Migrants, Refugees, and the National Order of Things." Alternatives 39 (3): 151-163.

Foucault, Michel. 1983. "On Genealogy of Ethics: An Overview of Work in Progress." In Michel Foucault: Beyond Structuralism and Hermenautics, edited by H. L. Dreyfus and P. Rabinow, 229-252. Chicago: The University of Chicago Press.

Gregor, Miloš, and Alena Macková. 2015. "Euroscepticism the Czech way: An analysis of Václav Klaus's speeches.” European Journal of Communication 30 (4): 404-417.

Hawkins, Kirk A. 2009. "Is Chávez Populist? Measuring Populist Discourse in Comparative perspective." Comparative Political Studies 42 (8): 1040-1067.

Kaniok, Petr, and Vlastimil Havlík. 2016. "Populism and Euroscepticism in the Czech Republic: Meeting Friends or Passing By?” Romanian Journal of European Affairs 16 (2): 20 35.

Kosárová, Dominika, and Jaroslav Ušiak. 2017. “The Role of Identity in the Global Terrorist Movement.” Politické vedy 20 (4): 113-133.

Krčál, Petr, and Vladimír Naxera, 2018. "Populistická konstrukce národa ohroženého migrací: CAQDAS volebního diskurzu českých parlamentních voleb v roce 2017.” Sociológia 50 (5): 491-523.

Krčál, Petr. 2017. “Sociální konstrukce extremismu v imaginaci Miloše Zemana." Acta Fakulty filozofické Západočeské univerzity v Plzni 9 (3): 73-92.

Laclau, Ernesto. 2005. On Populist Reason. London: Verso.

Lupták, Lubomír. 2017. (Ne)bezpečnost ako povolanie. Brno: Doplněk.

Mareš, Miroslav et al. 2015. Ne islámu! Protiislámská politika v České republice. Brno: Centrum pro studium demokracie a kultury.

Meernik, James, Michael and Ault. 2013. "The tactics of foreign policy agenda-setting: Issue choice and the president's weekly radio address." International Area Studies Review 16 (1): 74-88.

Moffitt, Benjamin, and Simon Tormey. 2014. "Rethinking Populism: Politics, Mediatisation and Political Style." Political Studies 62: 381-397.

Mudde, Cas. 2004. “The Populist Zeitgeist.” Government and Opposition 39 (4): 541-543.

Mudde, Cas. 2007. The Populist Radical Right in Europe. Cambridge: Cambridge University Press.

Naxera, Vladimír, and Petr Krčál. 2018. "”Islam or Russia?”: the Czech President Miloš Zeman's Perception of Security Threats." In Security Forum 2018, edited by Jaroslav Ušiak, and David Kollár, 90-99. Banská Bystrica: Interpolis.

Novotný, Lukáš. 2017. “Pegida a migrační politika." Central European Journal of Politics 3 (2): $39-54$.

Ogan, Christine, Lars Willnat, Rosemary Pennington, and Manaf Bashir. 2014. "The rise of anti-Muslim prejudice: Media and Islamophobia in Europe and the United States." The International Communication Gazette 76 (1): 27-46.

Ostřanský, Bronislav, ed. 2018. Islamofobie po česku: Český odpor vůči islámu, jeho východiska, projevy, souvislosti, presahy i paradoxy. Prague: Vyšehrad. 
Oswald, Austin G. 2017. "Improving outcomes with Qualitative data Analysis Software: A reflective journey." Qualitative Social Work 0 (0): 1-7.

Ricoeur, Paul. 1981. Hermeneutics and the Human Sciences: Essays on Language, Action and Interpretation. Cambridge: Cambridge University Press.

Riesigl, Martin. 2008. “Analysing political rhetoric.” In Qualitative Discourse Analysis in the Social Science, edited by Ruth Wodak and Michal Krzyznowski, 96-120. New York: Palgrave Macmillan.

Saldana, Johnny. 2009. The Coding Manual for Qualitative Researchers. 3rd Ed. London: SAGE Publication Ltd.

Sanders, Karen, Maria Jesús Molina Hurtado, and Jessica Zoragastua. 2017. "Populism and exclusionary narratives: The 'other' in Podemos' 2014 European Union election campaign." European Journal of Communication 32 (6): 552-567.

Scacco, Joshua M., and Kevin Coe. 2017. "Talk This Way: The Ubiquitous of Presidential Communication." American Behavioral Scientist 61 (3): 298-314.

Stulík, Ondřej. 2016. "Diskurzivní analýza Národních listů: národ vs. islám a Laclauův populistický matrix." Central European Political Studies Review 18 (2-3): 223-252.

Tarchi, Marco. 2016. "Populism: Ideology, Political Style, Mentality?" Czech Journal of Political Science 23 (2): 95-109.

Ušiak, Jaroslav, and Pavel Nečas. 2011. "Societálny a politický sektor v kontexte bezpečnosti štátu." Politické vedy 14 (1): 30-49.

Wolkenstein, Fabio. 2016. "Populism, liberal democracy and the ethics of peoplehood." European journal of Political Theory 0 (0): 1-19.

Woods, Dwayne, and Barbara Wejnert, eds. 2014. The Many Faces of Populism: Current Perspectives. Bingley: Emerald.

Žúborová, Viera, and Ingrid Borárosová. 2016. "Migrácia v médiách: utečenci verzus migranti. Chápanie migrantov a utečencov v mediálním priestore v kontexte pozitívnej a negatívnej mediatizácie." Central European Journal of Politics 2 (1): 1-15. 